\title{
Characteristics of patients with language disorders and the theory of multiple intelligences
}

Renata Gomes Camargo(1)

Carolina Lisbôa Mezzomo(2)

(1) Colégio de Aplicação da Universidade Federal de Santa Catarina - UFSC, Florianópolis, Santa Catarina, Brazil.

(2) Universidade Federal de Santa Maria UFSM Santa Maria, Rio Grande do Sul, Brazil.

Article developed at the Universidade Federal de Santa Maria, Santa Maria, Rio Grande do Sul, Brazil.

Conflict of interest: Nonexistent

Received on: February 20, 2017 Accept on: September 5, 2017

Mailing address:

Renata Gomes Camargo

Rua Capitão Romualdo de Barros, 965

ap. 304, Bloco C, Bairro Carvoeira -

Florianópolis, Santa Catarina, Brasil

CEP: 88040-600

E-mail: re_kmargo@hotmail.com

\section{ABSTRACT}

Purpose: to investigate which intelligence, described in the Theory of Multiple Intelligences, favors the development of language (linguistic intelligence) of the patients, in relation to the studied variables: development phase (children and adolescents), sex and preferential intelligences.

Methods: the quantitative-qualitative approach was used, with the identification by content analysis of the preferred intelligences of the 107 patients participating in the investigation and the intelligences contemplated in each therapy. After the coding of these data in numbers, the results obtained in the 1,802 therapies analyzed were compared with the development phase, sex and preferential intelligences, using a statistical test.

Results: in the analysis of the data, it was evidenced that the results obtained in the therapy differ between children and adolescents, according to the intelligences contemplated, which is also observed when considering females and males, but to a lesser extent.

Conclusion: it is important to observe the characteristics of age, sex and preferential intelligences, in relation to the contemplation of the different intelligences in the activities developed in the therapy, with a view to the qualification of the results.

Keywords: Language Therapy; Distribution by Age; Distribution by Sex; Intelligence 


\section{INTRODUCTION}

Reflecting on the aspects that can guide the planning of Speech Language Therapy, in addition to the evaluation and theoretical assumptions and/ or therapeutic models to be used, is a way of identifying factors involved in this planning, when considering aspects related to individuality of each patient. Generally, such factors are not considered a priori, but may have relevance to their performance and evolution.

Some authors have dedicated themselves to investigate and systematize evaluation methods and practices related to the adequate utilization of human intellectual capacity in different social contexts ${ }^{1-4}$. This research is based on the Multiple Intelligences Theory, in which eight intelligences are presented: linguistic, logical-mathematical, spatial, kinesthetic-corporal, musical, interpersonal, intrapersonal and naturalistic. Such intelligences are understood as relatively autonomous intellectual systems, which interact in cognition and express themselves in the actions of individuals in a way, still having one or more intelligences as their preferential.

It is understood that the preferential intelligences are those which, when contemplated in some activity, instigate greater interest in the subject over time, also being his or her more developed intelligences. This term was elaborated by the authors of this work.

Based on the intelligences mentioned, it is possible to study the indication of the types of resources and strategies to be used in Speech-Language Therapy for each stage of development. It is known that the characterization of these phases is widely diffused in the literature ${ }^{5-8}$. By associating the knowledge of the Theory of Multiple Intelligences to this characterization, the reflection on the visualization of the elements most related to each one of the named intelligences is added. These elements, when contemplated in therapy, may differ in each phase, as to be more instigating of patient's performance and evolution, in a specific aspect of development that is the acquisition of verbal language, understood as synonymous with linguistic intelligence.

Such an understanding is permeated by the view that, although the learning associated with each intelligence differentiates between them, as well as those related to the development of linguistic intelligence, these are interconnected and interacting in the human cognitive system 9,10. Thus, in contemplating the planned activity for the attendance, a certain intelligence, for example the kinesthetic-corporal, combined with another one, like the linguistic intelligence, interactions between these intelligences are established, in which one can interfere in the development of the other. These combinations can produce different results in working with verbal language at each stage of development and/or depending on the patient's gender. For example, it is highlighted that interpersonal intelligence and kinesthetic-corporal are present in combinations of intelligences that favor the verbal performance of children and that intrapersonal intelligence is often verified in these combinations related to adolescents. In this context, for the qualification of the the discussion, the FRAMES ${ }^{11}$ study is addressed, which are structures of knowledge present in the human intellect and which are interwoven by the eight intelligences.

It is important to pay attention to the singularities of the patients, in addition to the deficit in the verbal language they present. Therefore, their difficulties imply the need for certain skills to be worked on in the attendance ${ }^{12}$, a requirement that can be thought based on the knowledge of the different intelligences ${ }^{10}$.

Considering the observation of these singularities, this research is permeated by the characteristics of the subjects. Thus, the objective of the study was to investigate which intelligences favors the performance of the patients in the therapy, mainly the linguistic one, in relation to the studied variables: development phase (children and adolescents), sex and preferential intelligences.

\section{METHODS}

This study was approved by the Ethics and Research Committee of Universidade Federal de Santa Maria, under CAEE protocol number 36321214.1.0000.5346 and was set up as a cross-sectional, quantitative research. The sample was collected in 107 medical records of 33 female subjects and 74 male subjects, aged between two years and 17 years and 11 months. The diagnoses presented by the patients are systematized in Figure 1 and were transcribed as they were recorded in their medical records, so the diagnoses and data used in this study were elaborated by other professionals. 


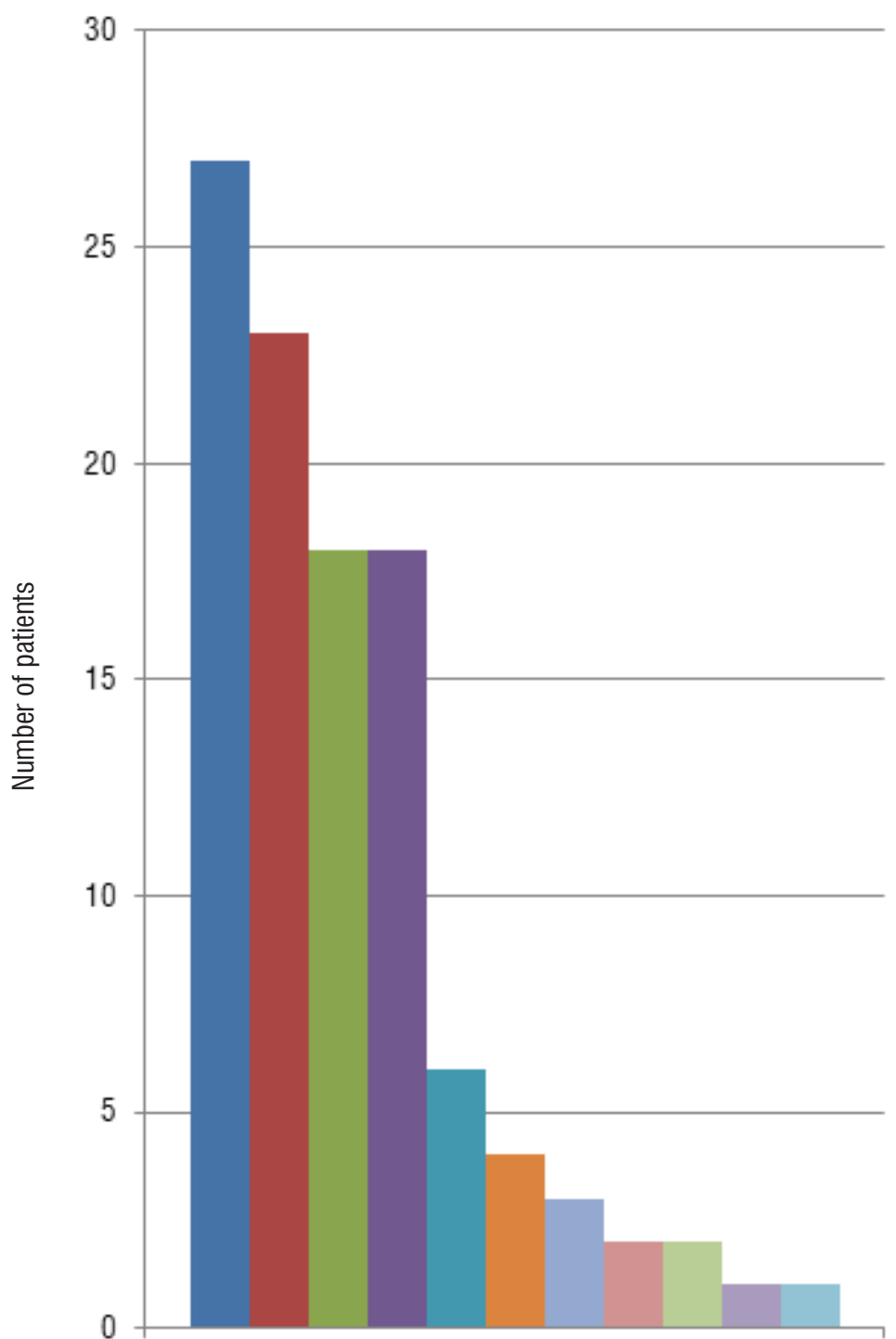

Diagnostics

\author{
- Phonological disorders \\ - Specific Language Disorder \\ - Language Disorder resulting \\ from Hearing Loss \\ Learning Difficulties \\ - Language Disorder resulting \\ from Down Syndrome \\ - Language Disorder resulting \\ from Intellectual Deficiency \\ Phonetic Deviation \\ n Disfluency/Stutter \\ Cleft Lip and Palate \\ - Language Disorder resulting \\ from Coffin-Siris Syndrome \\ - Language Disorder resulting \\ from Turner Syndrome
}

Subtitle:

Colors: Each color refers to a type of diagnosis.

Numbers: Frequency of patients with each type of diagnosis.

Diagnostics: Types of diagnostics at each frequency.

Figure 1. Frequency of patient diagnostic types

To perform one of the statistical analyzes, the sample was divided into two groups: children and adolescents. The first group consisted of patients aged up to nine years and 11 months and the second group of those aged from 10 years up to 19 years and 11 months. This division was based on the criteria established by the World Health Organization ${ }^{8}$.

Patients participating in the study attended speech therapy during the second half of 2014 and the first half of 2015. The therapy took place within the supervised stages of Hearing and Speech and Hearing
Rehabilitation, Speech and Oral and Written Language, in a Speech-Language Pathology and Audiology Service of the Speech, Language and Hearing Sciences Course of a public university in southern Brazil. All patients were invited to participate, however those included in the study were those whose therapists and parents or guardians accepted and authorized, respectively. Therapists who agreed to participate in the research should respond to a Structured Script of Therapy Evolution, on each attendance given. This script was composed of two descriptive items and the 
other objectives, and was formulated by the authors of this article.

The profile of the patients' preferential intelligences was established by the content analysis ${ }^{13}$ of the non-numerical data combined with the systematization of the numerical data of the information obtained in a questionnaire, created for this research and applied with the parents or guardians of the patients, with open and closed questions that contained information about the eight intelligences. They responded with a written registration to seven essay questions, for example, "What does your child like to do the most? Why? Give examples" and to 74 objective questions, which they should answer yes, no or sometimes. An example of these questions is" Does he/she like to draw or scribble?" The researchers were present during the application of the questionnaire, explaining it before the beginning of the registration, as well as solving doubts about the issues throughout the action. In addition, the parents or guardians could choose to answer questions orally. In this case, one of the researchers performed the registration.

These data were associated with the documentary research in the reports of attendance contained in the medical records. In this research, the last semester report was searched and analyzed to compose the profile of each research participant. The data of the profile of 22 patients, corresponding to $20 \%$ of the sample, were transferred to three judges from different areas (Speech Therapy, Education and Psychology), with knowledge of the Multiple Intelligences Theory, so that they could be analyzed and judged by them. The definition of this percentage was guided by a statistical professional. The percentage of agreement between the analysis of the researchers and the judges was $89 \%$. This action was performed to guarantee the reliability of the systematized data.

After the coding of the profiles into numbers, the Binomial Test was performed in the Statistica 7 software. This test made it possible to compare the proportions of the female and male sex, to verify if there was difference with statistical significance between the profiles of preferential intelligences of the patients of each sex.

The Structured Script of Therapy Evolution contained open and closed items for recording the results of the attendance. With the content analysis ${ }^{9}$ of the descriptive item, "Description of the activity and resources (materials) used", it was raised which of the eight intelligences were contemplated in each therapy, being the intelligences the categories of analysis chosen a priori. Such a survey was organized in a table, with the resources and strategies categorized according to their relation to each intelligence, as well as number-coded, for example, in a therapy in which linguistic intelligences were contemplated, coded by the number " 1 " and spatial, coded by the number " 3 ", the number 13 was assigned.

The objective questions of the script were composed of items organized in the following groups: verbal linguistic behavior (expression); verbal performance qualification; non-verbal linguistic behavior (expression); qualification of non-verbal performance; understanding; verbal linguistic behavior (reading and writing); interest in the activity; motivation in the activity; involvement in the task; the patient realized its effectiveness in the therapy; involvement of the therapist in the task. These groups were composed of items, which will be visualized in the results of the article, where the result of the therapy related to them is classified and registered by the numbers: (1) Frequently; (2) Sometimes; (3) Rarely and (4) Never (relation to extra therapy factors: illness, malaise, family problem, etc.) or (A) Totally, (B) Partially and (C) Never.

The data of the 107 patients who participated in the study were also tabulated in EXCEL worksheets in and converted to numbers for statistical purposes. Thus, for the male patients, the number " 0 " was assigned and for the female patients, the number "1"; they were also classified in children, where the number " 0 " was assigned for children and the number "1" for adolescents. After this coding, the data were divided and allocated in new tables, from the characteristics age and sex.

With the data found in each item of the Structured Script of Evolution regarding the results, the descriptive statistics were performed, with tables being drawn in the EXCEL software, with transcription of the data and a survey of the frequency of each response in the items. With the data coded and categorized, the KruskalWallis statistical test was applied by the researchers in the Statistica 7 software, under the supervision of a trained professional.

In this test, the results of 1802 speech language therapies were compared, observing in which items in the script was verified a difference with statistical significance ( $p \leq 0.05)$, of the therapies in which each intelligence was contemplated or the combination of these. In the results of the script items in which this difference was verified, the Multiple Comparison Test was applied, 
in the same statistical software previously reported, to ascertain which intelligences differed from each other. This analysis demonstrated the intelligences contemplated in the therapy, in which the patients presented the best results, in relation to their age and gender.

\section{RESULTS}

In Figure 2, the results of the comparisons between the intelligences contemplated in the therapies performed with the child patients were presented.

In Figure 3, the results of the comparisons between the intelligences contemplated in the therapies performed with the adolescent patients were presented.

\begin{tabular}{|c|c|c|c|}
\hline \multirow[b]{2}{*}{ Evolution script items } & \multirow[b]{2}{*}{$P$ value } & \multicolumn{2}{|c|}{ Interpretation of results } \\
\hline & & $\begin{array}{c}\text { Intelligences with low scores } \\
\text { (higher results) }\end{array}$ & $\begin{array}{c}\text { Intelligences with high scores } \\
\text { (lower results) }\end{array}$ \\
\hline $\begin{array}{l}\text { The patient presented communicative } \\
\text { intention }\end{array}$ & $p>0.05$ & - & - \\
\hline The patient used vocalizations & $p>0.05$ & - & - \\
\hline The patient used isolated words & $p>0.05$ & - & - \\
\hline \multirow{10}{*}{$\begin{array}{l}\text { The patient used phrases (simple and } \\
\text { complex) }\end{array}$} & \multirow{10}{*}{$p \leq 0.05$} & \multirow{2}{*}{ Linguistics } & Kinesthetic-corporal \\
\hline & & & Musical \\
\hline & & Linguistics and Spatial & \multirow{2}{*}{ Kinesthetic-corporal and Musical } \\
\hline & & Linguistics and Kinesthetic-Corporal & \\
\hline & & Linguistics and Interpersonal & \multirow{2}{*}{$\begin{array}{c}\text { Kinesthetic-corporal and } \\
\text { Interpersonal }\end{array}$} \\
\hline & & Spatial and Kinesthetic-Corporal & \\
\hline & & Linguistics and Spatial & \multirow{3}{*}{$\begin{array}{l}\text { Kinesthetic-corporal and Musical } \\
\text { Kinesthetic-corporal and } \\
\text { Interpersonal }\end{array}$} \\
\hline & & Linguistics and Kinesthetic-Corporal & \\
\hline & & Linguistics and Interpersonal & \\
\hline & & Spatial and Kinesthetic-Corporal & $\begin{array}{l}\text { Kinesthetic-corporal and } \\
\text { Interpersonal }\end{array}$ \\
\hline \multirow{2}{*}{ The patient made reports } & \multirow{2}{*}{$p \leq 0.05$} & Linguistics & \multirow{2}{*}{ Kinesthetic-corporal } \\
\hline & & Spatial & \\
\hline \multirow{3}{*}{$\begin{array}{l}\text { The patient used non-symbolic } \\
\text { gestures }\end{array}$} & \multirow{3}{*}{$p \leq 0.05$} & Spatial and Musical & Linguistics and Spatial \\
\hline & & $\begin{array}{l}\text { Kinesthetic-corporal and } \\
\text { Interpersonal }\end{array}$ & Linguistics and Interpersonal \\
\hline & & $\begin{array}{l}\text { Kinesthetic-corporal and } \\
\text { Interpersonal }\end{array}$ & Spatial and Kinesthetic-Corporal \\
\hline The patient used symbolic gestures & $p>0.05$ & - & - \\
\hline $\begin{array}{l}\text { The patient used eye shifting (eye } \\
\text { contact) }\end{array}$ & $p>0.05$ & - & - \\
\hline $\begin{array}{c}\text { The patient used expressions of } \\
\text { approval }\end{array}$ & $p>0.05$ & - & - \\
\hline $\begin{array}{c}\text { The patient used expressions of } \\
\text { disapproval }\end{array}$ & $p \leq 0.05$ & Spatial and Musical & Linguistics and Spatial \\
\hline $\begin{array}{l}\text { The patient needs an association of } \\
\text { gestures to understand }\end{array}$ & $p \leq 0.05$ & Spatial and Musical & Linguistics and Interpersonal \\
\hline \multirow{3}{*}{$\begin{array}{l}\text { The patient comprises order and/or } \\
\text { information related to the immediate } \\
\text { context }\end{array}$} & \multirow{3}{*}{$p \leq 0.05$} & Linguistics & Kinesthetic-corporal \\
\hline & & Linguistics and Spatial & Spatial and Musical \\
\hline & & $\begin{array}{c}\text { Linguistics, Spatial and Kinesthetic- } \\
\text { Corporal }\end{array}$ & $\begin{array}{l}\text { Spatial, Interpersonal and } \\
\text { Intrapersonal }\end{array}$ \\
\hline
\end{tabular}




\begin{tabular}{|c|c|c|c|}
\hline \multirow[b]{2}{*}{ Evolution script items } & \multirow[b]{2}{*}{$P$ value } & \multicolumn{2}{|c|}{ Interpretation of results } \\
\hline & & $\begin{array}{l}\text { Intelligences with low scores } \\
\text { (higher results) }\end{array}$ & $\begin{array}{l}\text { Intelligences with high scores } \\
\text { (lower results) }\end{array}$ \\
\hline \multirow{9}{*}{$\begin{array}{l}\text { The patient comprises order and/ } \\
\text { or information not related to the } \\
\text { immediate context }\end{array}$} & \multirow{9}{*}{$p \leq 0.05$} & \multirow{2}{*}{ Linguistics } & Kinesthetic-corporal \\
\hline & & & Musical \\
\hline & & $\begin{array}{l}\text { Linguistics and Spatial } \\
\text { Linguistics and Interpersonal }\end{array}$ & $\begin{array}{l}\text { Spatial and Musical } \\
\text { Kinesthetic-corporal and } \\
\text { Interpersonal }\end{array}$ \\
\hline & & Linguistics and Interpersonal & Kinesthetic-corporal and Musical \\
\hline & & \multirow[b]{2}{*}{ Spatial and Kinesthetic-Corporal } & Spatial and Musical \\
\hline & & & $\begin{array}{l}\text { Kinesthetic-corporal and } \\
\text { Interpersonal }\end{array}$ \\
\hline & & $\begin{array}{l}\text { Linguistics, Spatial and Kinesthetic- } \\
\text { Corporal }\end{array}$ & \multirow{2}{*}{$\begin{array}{l}\text { Spatial, Interpersonal and } \\
\text { Intrapersonal }\end{array}$} \\
\hline & & $\begin{array}{l}\text { Linguistics, Kinesthetic-Corporal and } \\
\text { Interpersonal }\end{array}$ & \\
\hline & & $\begin{array}{l}\text { Linguistics, Spatial, Musical and } \\
\text { Intrapersonal }\end{array}$ & $\begin{array}{l}\text { Spatial, Kinesthetic-corporal, Musical } \\
\text { and Interpersonal }\end{array}$ \\
\hline $\begin{array}{c}\text { Verbal linguistic behavior (reading and } \\
\text { writing) }\end{array}$ & $p>0.05$ & - & - \\
\hline Interest in the activity & $p>0.05$ & $p>0,05$ & - \\
\hline Motivation in the activity & $p>0.05$ & $p>0,05$ & - \\
\hline Involvement in the task & $p>0.05$ & $p>0,05$ & - \\
\hline $\begin{array}{l}\text { The patient perceived its effectiveness } \\
\text { in the therapy }\end{array}$ & $p>0.05$ & $p>0,05$ & - \\
\hline Involvement of the therapist in the task & $p>0.05$ & $p>0,05$ & - \\
\hline
\end{tabular}

Legend: Statistical tests: Kruskal-Wallis and Multiple Comparison Test, $p \leq 0.05$.

Figure 2. Results and interpretation of the statistical analysis of comparison between the intelligences contemplated in the therapy, in relation to the data of the structured script of the children's therapy 


\begin{tabular}{|c|c|c|c|}
\hline \multirow[b]{2}{*}{ Evolution script item } & \multirow[b]{2}{*}{$P$ value } & \multicolumn{2}{|c|}{ Interpretation of results } \\
\hline & & $\begin{array}{l}\text { Intelligences with low scores } \\
\text { (higher results) }\end{array}$ & $\begin{array}{l}\text { Intelligences with high scores } \\
\text { (lower results) }\end{array}$ \\
\hline $\begin{array}{c}\text { The patient presented communicative } \\
\text { intention }\end{array}$ & $p>0.05$ & - & - \\
\hline The patient used vocalizations & $p \leq 0.05$ & Linguistics, Spatial and Musical & $\begin{array}{c}\text { Logical-Mathematical, Spatial and } \\
\text { Musical }\end{array}$ \\
\hline \multirow[b]{2}{*}{ The patient used isolated words } & \multirow[b]{2}{*}{$p \leq 0.05$} & Linguistics, Spatial and Musical & \multirow[b]{2}{*}{$\begin{array}{l}\text { Logical-Mathematical, Spatial and } \\
\text { Musical }\end{array}$} \\
\hline & & $\begin{array}{l}\text { Linguistics, Musical and } \\
\text { Intrapersonal }\end{array}$ & \\
\hline $\begin{array}{l}\text { The patient used phrases (simple and } \\
\text { complex) }\end{array}$ & $p>0.05$ & - & - \\
\hline The patient reported & $p>0.05$ & - & - \\
\hline \multirow[b]{2}{*}{ The patient used non-symbolic gestures } & \multirow[b]{2}{*}{$p \leq 0.05$} & Linguistics, Spatial and Musical & \multirow{2}{*}{$\begin{array}{l}\text { Logical-Mathematical, Spatial and } \\
\text { Musical }\end{array}$} \\
\hline & & $\begin{array}{l}\text { Linguistics, Musical and } \\
\text { Intrapersonal }\end{array}$ & \\
\hline The patient used symbolic gestures & $p>0.05$ & - & - \\
\hline The patient used eye shifting (eye contact) & $p>0.05$ & - & - \\
\hline The patient used expressions of approval & $p>0.05$ & - & - \\
\hline The patient used expressions of disapproval & $p>0.05$ & - & - \\
\hline \multirow{2}{*}{$\begin{array}{l}\text { The patient needs an association of } \\
\text { gestures to understand }\end{array}$} & \multirow{2}{*}{$p \leq 0.05$} & $\begin{array}{l}\text { Linguistics, Musical and } \\
\text { Intrapersonal }\end{array}$ & \multirow{2}{*}{ Linguistics, Spatial and Musical } \\
\hline & & $\begin{array}{c}\text { Logical-Mathematical, Spatial and } \\
\text { Musical }\end{array}$ & \\
\hline $\begin{array}{l}\text { The patient comprises order and/or } \\
\text { information related to the immediate context }\end{array}$ & $p \leq 0.05$ & Linguistics and Intrapersonal & Spatial and Musical \\
\hline $\begin{array}{l}\text { Verbal linguistic behavior (reading and } \\
\text { writing) }\end{array}$ & $p>0.05$ & - & - \\
\hline Interest in the activity & $p>0.05$ & - & - \\
\hline Motivation in the activity & $p>0.05$ & - & - \\
\hline Involvement in the task & $p>0.05$ & - & - \\
\hline $\begin{array}{c}\text { The patient perceived its effectiveness in the } \\
\text { therapy }\end{array}$ & $p>0.05$ & - & - \\
\hline Involvement of the therapist in the task & $p>0.05$ & - & - \\
\hline
\end{tabular}

Legend: Statistical tests: Kruskal-Wallis and Multiple Comparison Test, $p \leq 0.05$.

Figure 3. Results and interpretation of the statistical analysis of comparison between the intelligences contemplated in the therapy, in relation to the data of the structured script of evolution of the adolescent patient therapy

The results of the statistical test showed that in both groups, children and adolescents, among the intelligences that give the best results to therapy, stand out linguistic, spatial and musical, diversifying the combinations between them and/or with other intelligences. It is also emphasized that interpersonal and kinestheticcorporal intelligence are present in the combinations with statistical significance in the group of children and in none of the adolescents. Intrapersonal intelligence is verified only in a combination with statistical significance in the group of children and is very frequent in those of the group of adolescents.

The results of the comparisons between the intelligences contemplated in the therapies performed with the female patients were presented in Figure 4.

Finally, the results of comparisons between the intelligences contemplated in the therapies performed with the male patients were presented in Figure 5. 


\begin{tabular}{|c|c|c|c|}
\hline \multirow[b]{2}{*}{ Evolution script item } & \multirow[b]{2}{*}{$P$ value } & \multicolumn{2}{|c|}{ Interpretation of results } \\
\hline & & $\begin{array}{l}\text { Intelligences with low scores } \\
\text { (higher results) }\end{array}$ & $\begin{array}{l}\text { Intelligences with high scores } \\
\text { (lower results) }\end{array}$ \\
\hline $\begin{array}{c}\text { The patient presented communicative } \\
\text { intention }\end{array}$ & $p>0.05$ & - & - \\
\hline The patient used vocalizations & $p>0.05$ & - & - \\
\hline The patient used isolated words & $p>0.05$ & - & - \\
\hline \multirow{4}{*}{$\begin{array}{l}\text { The patient used phrases (simple and } \\
\text { complex) }\end{array}$} & \multirow{4}{*}{$p \leq 0.05$} & \multirow{2}{*}{ Linguistics } & Spatial \\
\hline & & & Interpersonal \\
\hline & & Linguistics and Spatial & $\begin{array}{l}\text { Kinesthetic-corporal and } \\
\text { Interpersonal }\end{array}$ \\
\hline & & Linguistics and Interpersonal & $\begin{array}{l}\text { Kinesthetic-corporal and } \\
\text { Interpersonal }\end{array}$ \\
\hline The patient reported & $p>0.05$ & - & - \\
\hline \multirow{2}{*}{$\begin{array}{l}\text { The patient used non-symbolic } \\
\text { gestures }\end{array}$} & \multirow[b]{2}{*}{$p \leq 0.05$} & Spatial and Musical & Linguistics and Spatial \\
\hline & & $\begin{array}{l}\text { Kinesthetic-corporal and } \\
\text { Interpersonal }\end{array}$ & Linguistics and Spatial \\
\hline The patient used symbolic gestures & $p>0.05$ & - & - \\
\hline $\begin{array}{l}\text { The patient used eye shifting (eye } \\
\text { contact) }\end{array}$ & $p>0.05$ & - & - \\
\hline $\begin{array}{l}\text { The patient used expressions of } \\
\text { approval }\end{array}$ & $p>0.05$ & - & - \\
\hline $\begin{array}{l}\text { The patient used expressions of } \\
\text { disapproval }\end{array}$ & $p>0.05$ & - & - \\
\hline \multirow{3}{*}{$\begin{array}{l}\text { The patient needs an association of } \\
\text { gestures to understand }\end{array}$} & \multirow{3}{*}{$p \leq 0.05$} & \multirow{3}{*}{ Spatial and Musical } & Linguistics and Spatial \\
\hline & & & Linguistics and Interpersonal \\
\hline & & & Linguistics and Intrapersonal \\
\hline $\begin{array}{l}\text { The patient comprises order and/or } \\
\text { information related to the immediate } \\
\text { context }\end{array}$ & $p>0.05$ & - & - \\
\hline $\begin{array}{l}\text { The patient comprises order and/ } \\
\text { or information not related to the } \\
\text { immediate context }\end{array}$ & $p>0.05$ & - & - \\
\hline $\begin{array}{c}\text { Verbal linguistic behavior (reading and } \\
\text { writing) }\end{array}$ & $p>0.05$ & - & - \\
\hline Interest in the activity & $p>0.05$ & - & - \\
\hline Motivation in the activity & $p>0.05$ & - & - \\
\hline Involvement in the task & $p>0.05$ & - & - \\
\hline $\begin{array}{l}\text { The patient perceived its effectiveness } \\
\text { in the therapy }\end{array}$ & $p>0.05$ & - & - \\
\hline Involvement of the therapist in the task & $p>0.05$ & - & - \\
\hline
\end{tabular}

Legend: Statistical tests: Kruskal-Wallis and Multiple Comparison Test, $p \leq 0.05$.

Figure 4. Results and interpretation of the statistical analysis of comparison between the intelligences contemplated in the therapy, in relation to the data of the structured script of evolution of the therapy, of female patients 


\begin{tabular}{|c|c|c|c|}
\hline \multirow[b]{2}{*}{ Evolution script item } & \multirow[b]{2}{*}{$P$ value } & \multicolumn{2}{|c|}{ Interpretation of results } \\
\hline & & $\begin{array}{l}\text { Intelligences with low scores } \\
\text { (higher results) }\end{array}$ & $\begin{array}{l}\text { Intelligences with high scores } \\
\text { (lower results) }\end{array}$ \\
\hline $\begin{array}{l}\text { The patient presented communicative } \\
\text { intention }\end{array}$ & $p>0.05$ & - & - \\
\hline The patient used vocalizations & $p>0.05$ & - & - \\
\hline The patient used isolated words & $p>0.05$ & - & - \\
\hline \multirow{2}{*}{$\begin{array}{l}\text { The patient used phrases (simple and } \\
\text { complex) }\end{array}$} & \multirow[b]{2}{*}{$p \leq 0.05$} & Linguistics & Kinesthetic-corporal \\
\hline & & Linguistics and Interpersonal & $\begin{array}{c}\text { Kinesthetic-corporal and } \\
\text { Interpersonal }\end{array}$ \\
\hline \multirow{7}{*}{ The patient reported } & \multirow{7}{*}{$p \leq 0.05$} & Linguistics & \multirow{2}{*}{ Kinesthetic-corporal } \\
\hline & & Spatial & \\
\hline & & Linguistics and Spatial & \multirow{5}{*}{$\begin{array}{l}\text { Kinesthetic-corporal and } \\
\text { Interpersonal }\end{array}$} \\
\hline & & Linguistics and Kinesthetic-Corporal & \\
\hline & & Linguistics and Interpersonal & \\
\hline & & Linguistics and Intrapersonal & \\
\hline & & Spatial and Kinesthetic-Corporal & \\
\hline \multirow{3}{*}{$\begin{array}{l}\text { The patient used non-symbolic } \\
\text { gestures }\end{array}$} & \multirow{3}{*}{$p \leq 0.05$} & Spatial and musical & Linguistics and Interpersonal \\
\hline & & $\begin{array}{l}\text { Kinesthetic-corporal and } \\
\text { Interpersonal }\end{array}$ & Linguistics and Interpersonal \\
\hline & & $\begin{array}{l}\text { Linguistics, Musical and } \\
\text { Intrapersonal }\end{array}$ & $\begin{array}{c}\text { Logical-Mathematical, Spatial and } \\
\text { Musical }\end{array}$ \\
\hline The patient used symbolic gestures & $p \leq 0.05$ & Linguistics & Spatial \\
\hline $\begin{array}{l}\text { The patient used eye shifting (eye } \\
\text { contact) }\end{array}$ & $p>0.05$ & - & - \\
\hline $\begin{array}{l}\text { The patient used expressions of } \\
\text { approval }\end{array}$ & $p>0.05$ & - & - \\
\hline $\begin{array}{l}\text { The patient used expressions of } \\
\text { disapproval }\end{array}$ & $p>0.05$ & - & - \\
\hline \multirow{4}{*}{$\begin{array}{l}\text { The patient needs an association of } \\
\text { gestures to understand }\end{array}$} & \multirow{4}{*}{$p \leq 0.05$} & \multirow{2}{*}{ Kinesthetic-corporal } & Linguistics \\
\hline & & & Spatial \\
\hline & & $\begin{array}{c}\text { Spatial, Interpersonal and } \\
\text { Intrapersonal }\end{array}$ & \multirow{2}{*}{$\begin{array}{l}\text { Logical-Mathematical, Spatial and } \\
\text { Musical }\end{array}$} \\
\hline & & $\begin{array}{c}\text { Kinesthetic-corporal, Musical and } \\
\text { Interpersonal }\end{array}$ & \\
\hline $\begin{array}{c}\text { The patient comprises order and/or } \\
\text { information related to the immediate } \\
\text { context }\end{array}$ & $p>0.05$ & - & - \\
\hline $\begin{array}{l}\text { The patient comprises order and/ } \\
\text { or information not related to the } \\
\text { immediate context }\end{array}$ & $p>0.05$ & - & - \\
\hline $\begin{array}{c}\text { Verbal linguistic behavior (reading and } \\
\text { writing) }\end{array}$ & $p>0.05$ & - & - \\
\hline Interest in the activity & $p>0.05$ & - & - \\
\hline Motivation in the activity & $p>0.05$ & - & - \\
\hline Involvement in the task & $p>0.05$ & - & - \\
\hline $\begin{array}{l}\text { The patient perceived its effectiveness } \\
\text { in the therapy }\end{array}$ & $p>0.05$ & - & - \\
\hline $\begin{array}{c}\text { Involvement of the therapist in the } \\
\text { task }\end{array}$ & $p>0.05$ & - & - \\
\hline
\end{tabular}

Legend: Statistical tests: Kruskal-Wallis and Multiple Comparison Test, $\mathrm{p} \leq 0.05$.

Figure 5. Results and interpretation of the statistical analysis of comparison between the intelligences contemplated in the therapy, in relation to the data of the structured script of evolution of the therapy, of male patients 
Based on the content of Figures 4 and 5, it is verified that more data were found with statistical significance in the group of male patients. This occurrence was possibly since the sample of the patients of this sex was twice as large as the female sample.
A descriptive statistical analysis was performed on the frequency of patients' preferred intelligence profiles, with 49 observations of male patients and 26 female patients, shown in Figure 6.

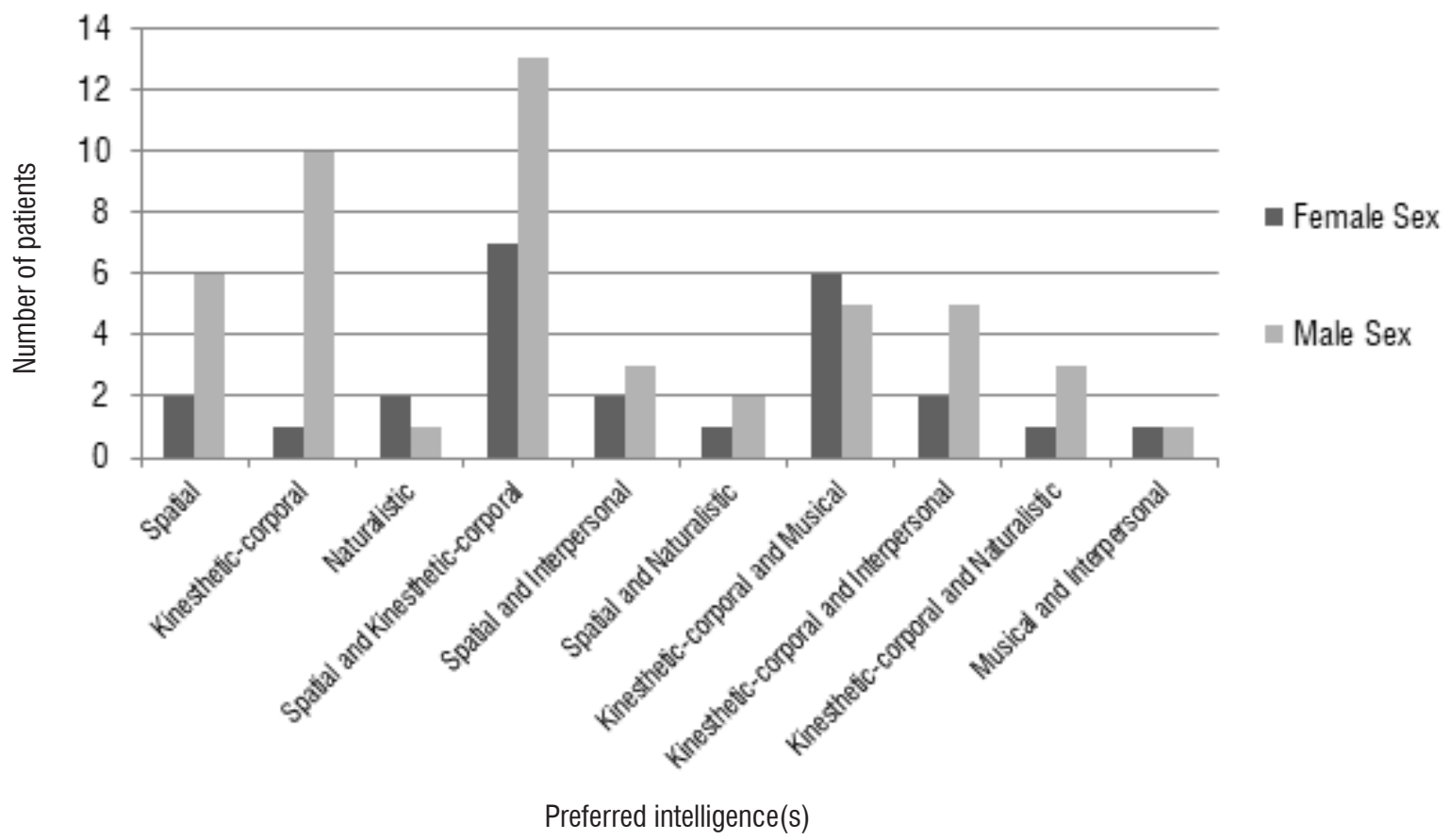

Black Color: Female. Gray Color: Male.

Numbers: Frequency of patients with each type of preferred intelligence (s).

Preferential Intelligence (s): Type of intelligence (s) at each frequency.

Figure 6. Comparison between females and males on the frequency of patient types of preferential intelligences

The three most frequent preferential intelligence profiles were: first, the combination, kinesthetic-corporal and spatial in both sexes. Following it, in the male patients, there is the kinesthetic-in second place, and spatial in third place; as for the in female patients, the kinesthetic-corporal and musical in second place, and tied in third place, with two patients, in each intelligence or combination: spatial; naturalistic, spatial and interpersonal and kinesthetic-corporal and interpersonal.
In the Binomial Test result, the only intelligence in which a statistically significant difference was found was the kinesthetic-corporal $(p=0.003)$. This data indicated that this intelligence, as preferential, has a significantly higher frequency in males than in females.

Figure 7 shows the frequency of the profiles of preferential intelligences that appeared exclusively in male patients. 


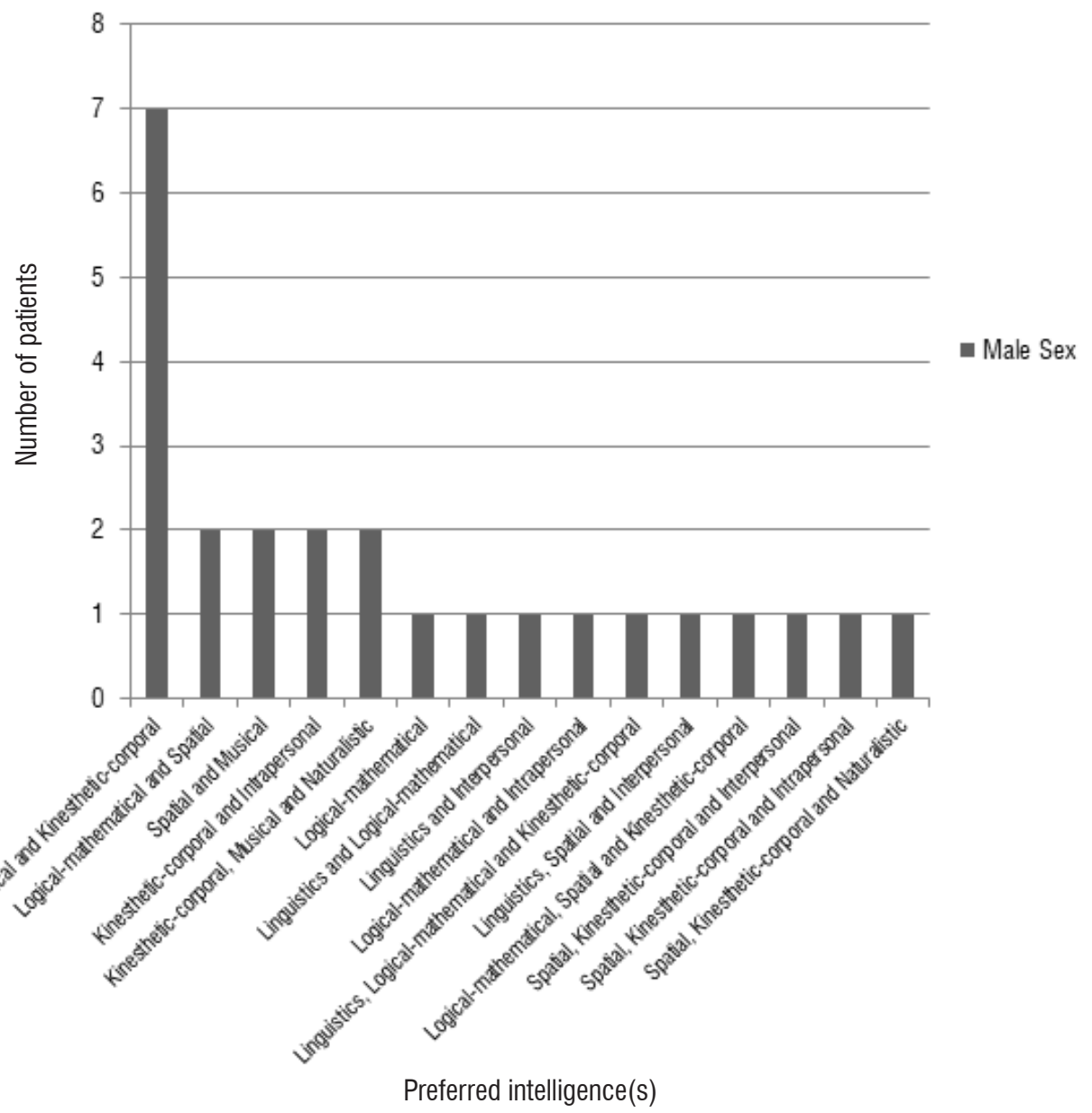

Black Color: Masculine.

Numbers: Frequency of patients with each type of preferred intelligence (s).

Preferential Intelligence (s): Type of intelligence (s) at each frequency.

Figure 7. Frequency of preferential types of intelligences of patients. intelligences or combinations that appeared exclusively in male patients

Figure 8 shows the frequency of the profiles of preferential intelligences that appeared exclusively in female patients.

Preferred intelligence combinations that appeared exclusively in one sex were 25 for males and 8 for females. The profile with logical-mathematical and kinesthetic-corporal intelligences was the most frequent in male patients (seven patients). Then, with two patients with each combination in their profile: logical-mathematical and spatial, spatial and musical, kinesthetic-corporal and intrapersonal and kinestheticcorporal, musical and naturalistic. As for the female patients, the most frequent profile is the spatial and intrapersonal intelligences, with two patients, the other combinations were represented by only one patient in each one. 


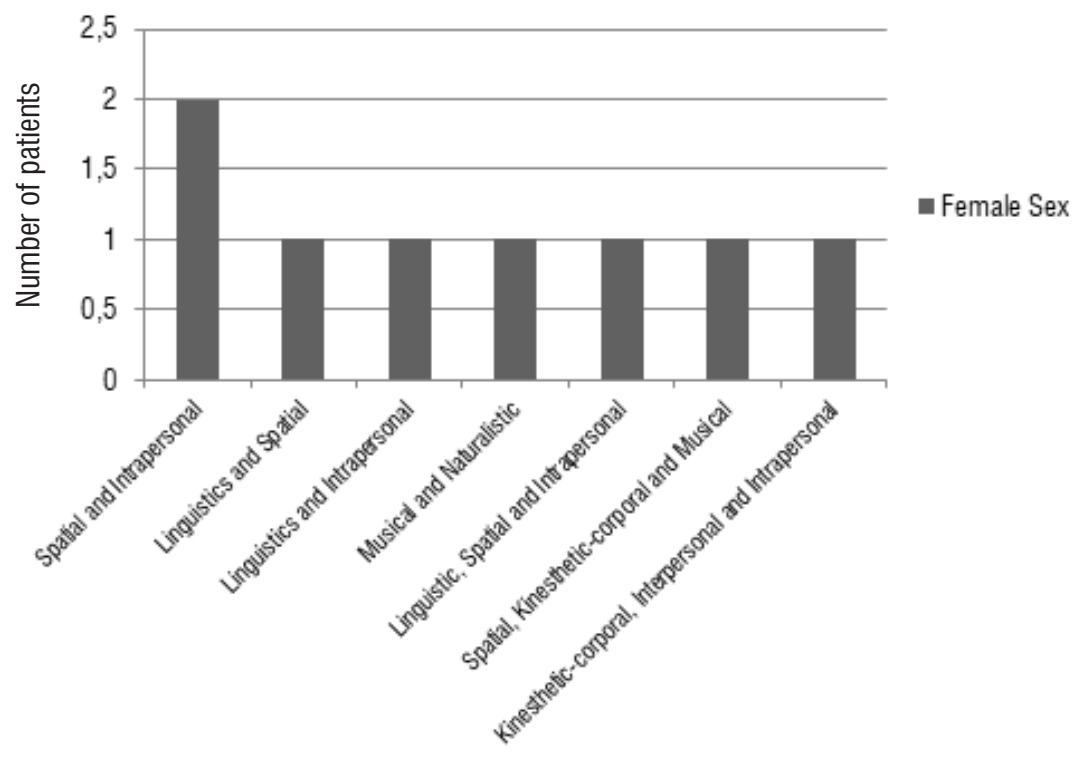

Preferred intelligence(s)

Black Color: Female.

Numbers: Frequency of patients with each type of preferred intelligence (s).

Preferential Intelligence (s): Type of intelligence (s) at each frequency.

Figure 8. Frequency of preferential types of intelligences of patients. intelligences or combinations which appeared only in female patients

\section{DISCUSSION}

To search for variables, age and sex, of patients with atypical acquisition or development of language ${ }^{14}$, related to the Multiple Intelligences Theory is a new proposal to systematize speech therapy addressed to the studied population. Many studies show that, in addition to the characteristics linked to diagnosis, individual characteristics interfere with performance and evolution in therapy, such as language, and/or readiness for new school learning ${ }^{15-17}$. Therefore, it is important to value the singularities of children and adolescents to obtain better results in therapy.

Age was investigated from the understanding of developmental stages, in which the patients were grouped into children and adolescents. The analysis and discussion of the data were based on the study of the proposals of activities elaborated for the therapy and the contemplation of the eight types of intelligences through the resources and strategies used. The results showed that children and adolescents have unequal characteristics, both in terms of which levels of linguistic complexity they differ, and in the intelligences that, when contemplated in the therapy, generate better results.

In the group of children, differences in performance with statistical significance were observed in the more complex levels of verbal expression (phrases and reports) and, in the group of adolescents, in less complex phases (isolated words) and in other means of communication (vocalizations). These results can be understood in relation to the influence of the level of linguistic development of the patients who composed the sample of this research on the results, and the data with statistical significance of the children possibly refer to those that already express themselves with greater complexity and, of the adolescents, refer to those who have the greatest commitment of language. However, it is believed that the richness of the data is in the observation of which intelligences can be contemplated in the therapy to obtain better results, in certain linguistic abilities with the adolescents and, in others, with the children. This identification can be visualized in Figure 2.

Both groups of children and adolescents presented differences between the intelligences contemplated in the items related to non-symbolic gestures and verbal comprehension at the less complex and intermediate levels. The two abilities refer to interpersonal intelligence, which is related to the ability to interact and understand the other, so this ability needs to be worked on in the patients, however observing and using the resources and strategies related to the other 
intelligences identified as instigating the best results in each group.

In the group of children, both in verbal and non-verbal expression and in comprehension, represented in the items in Figure 2, the intelligences that generate better results when contemplated in therapy were: kinesthetic-corporal and spatial, mainly and, interpersonal, the three isolated or combined with linguistics. For adolescents, linguistic intelligence, isolated and/or combined (mainly with spatial and/ or musical and/or intrapersonal intelligence), when contemplated through the resources and strategies used in therapy, is the one that provides better results in relation to other intelligences (Figure 3).

Each intelligence comprises a set of abilities and knowledges, but these can interact with those of another intelligence, due to the complexity of the cognitive processes involved in the performance of different activities by human beings 2,3,9. These sets can be visualized as cognitive and semantic FRAMES, which are structures of knowledge systematized in the cognition that, respectively, are or are not constituted and ran by the linguistic intelligence/verbal language ${ }^{11}$.

Based on the results of this research, it is understood that the therapeutic resources and strategies of linguistic intelligence that are related to the semantic FRAMES, combined with those of the kinestheticcorporal intelligences and spatial, which are related to certain cognitive FRAMES, are the most instigating of the acquisition and development of linguistic intelligence by children. For example, an activity of orality (linguistic intelligence) with actions of fine or broad movement (kinesthetic-corporal intelligence) and/ or with representations of spaces or with the use of objects or figures (spatial intelligence). Some studies address this type of work as one that brings the importance of non-verbal cognition to the development of playability, executive functions and verbal language ${ }^{18}$. Another study shows that sensory-motor enrichment helps in the promotion of verbal comprehension ${ }^{19}$, an investigation shows activities with videos as qualifiers of verbal language ${ }^{20}$, and a research that points to the use of figures as favoring pragmatic and attention abilities ${ }^{21}$.

The interpersonal intelligence proves to be important in the qualification of children's verbal language, both in understanding and expression. Due to their age, as well as the difficulties of interaction that arise from the deficit they present, ${ }^{22}$ the child patients need to develop the abilities related to this intelligence that relate to the ability to communicate and to relate socially, among others.

This indication is present in many papers, for example, one in which the positive correlation between children's performance in relation to emotional intelligence was verified, for example in the recognition of emotions in others and their performance in verbal language activities ${ }^{23}$. Artigas-Pallares and Paula-Pérez ${ }^{24}$ and Greenslade and Coggins ${ }^{25}$ assert that the interest in understanding and interacting with other people's behaviors are primary factors for global development and linguistic intelligence. This set of scientific evidences points to the importance of working with the abilities of interpersonal intelligence to favor the development of children's verbal language.

In the group of adolescent patients, the semantic FRAMES mainly stand out, because in almost all combinations of intelligences that favor the development of verbal language, linguistic intelligence is present. Therefore, the approach to resources and strategies strictly related to the contemplation of this intelligence is essential to the work with adolescent patients, for example, books, dialogues and games of questions and answers.

In addition, in the proposal of Grammar of Constructions ${ }^{26}$, which is based on the knowledge about FRAMES ${ }^{27}$, the study and valorization of the meaning of language constructions is approached as more relevant than the study of their structures and possible combinations. This assertion is understood as related to linguistic intelligence, in relation to the selection of these constructions to be worked on in therapy, mainly with respect to the result of verbal comprehension in the group of adolescents.

Also, in this group, intrapersonal intelligence stands out, and such intelligence is based both on self-knowledge and on topics of interest while the adolescent is in therapy. In the group of adolescents, more data were found with statistical significance in the linguistic and intrapersonal intelligences. This result shows that the strategy or resource selected for the therapeutic activity must be extremely significant for these patients, which implies in the careful choice of activities. It is worth mentioning that logical-mathematical intelligence appears only in the results of the group of adolescents. This finding may be associated with the fact that this intelligence begins to present itself in its most developed form in the early years of adolescence $^{28}$. 
The study of FRAMES related to the development of verbal language is important to recognize that much of the acquisition of this language is based on significant experiences related to language constructs 29. Therefore, it is important to know and recognize the prior knowledge of language therapy patients for the systematization of care ${ }^{30}$. In this sense, insofar as it is verified in the work with the linguistic abilities, irrespective of their level of complexity, that the same intelligences generate better results, in each of the groups, it is understood the relevance of using resources and strategies that contemplate them and that are meaningful to patients.

One of the most recurrent themes in the research on Multiple Intelligences Theory is the approach to the perception of lay people about sex, gender and social roles ${ }^{31-37}$. Among these, no investigations were found that contemplated the differences between the sexes of patients with altered language.

In both sexes, in the more complex levels of oral expression (phrases and reports), linguistic and interpersonal, mainly, and spatial, are the intelligences that, when contemplated in therapy, generate better results, to the detriment of combined kinesthetic-corporal or not with others. In the item "The patient used non-symbolic gestures", which corresponds to a non-verbal manifestation, the first four intelligences that give better results in both sexes are also non-verbal: spatial, musical, kinesthetic-corporal and interpersonal.

The spatial intelligence contemplated in the therapy alone or in combination corresponds to the most recurrent situation in which linguistics is not appreciated, directly in the resources and strategies used in the therapy, and better results are generated in the therapy than other intelligences. This intelligence coincides with the combination, with the highest number of patients, of both sexes, who present this as one of their preferred intelligences. In this sense, regardless of sex, addressing resources and strategies related to spatial intelligence tends to favor the occurrence of good results in language therapy.

It was observed that, in the male patients, a greater number of intelligences and combinations of them differed significantly in the results, than in the female patients. In the female patients, the kinesthetic-corporal, spatial, logical-mathematical, intrapersonal and musical intelligences stand out, appearing combined or not with linguistic intelligence. Kinesthetic-corporal intelligence, when contemplated in therapy, instigates better results in various abilities, and appears as significantly more frequent as preferential intelligence in male patients. Therefore, activities involving movement are useful to the therapeutic work with boys.

It is interesting to note that in both sexes the most frequent combination of preferential intelligences is the same: spatial and kinesthetic-corporal. In the combinations that appeared exclusively in each sex, male and female patients differ in the intelligences that compose the preferential intelligence profiles, being more frequent the kinesthetic-corporal, logical-mathematical and spatial in the first place; the spatial and intrapersonal, in the second place. Many studies have presented the different perceptions of men and women, about their intelligence and/or their partners and/or their parents and/or their children. In most of these, it was found that there is a different understanding of the sexes in relation to the greater development of the intelligences and better performance in the activities related to them: masculine, mainly, in the spatial and logicalmathematical intelligences, and feminine, mainly in the interpersonal ${ }^{31-37}$.

In this sense, when comparing the results of this investigation with these studies, it is verified that they are partially similar. Patients of both sexes present better results in therapy from work with the same intelligences, especially linguistics combined with spatial intelligence or interpersonal intelligence. Also, patients of both sexes have spatial intelligence as one of their most frequent preferred intelligences. On the other hand, it was found the logical-mathematical intelligence, only among the preferential ones of the male patients, agreeing with the studies that showed that the general perception of the people is that the subjects of this sex present this intelligence more developed than the female subjects.

\section{CONCLUSION}

Children and adolescents differ in the results obtained, in relation to the intelligences contemplated in therapy, through the resources and strategies selected by the therapists. This is very important for the planning of attendance, since, for example, an activity or game that is thought-provoking for the child's language development may not be for the adolescent, and vice versa. Therefore, it is necessary to select these elements considering such specificity.

Male and female patients differ less in relation to the diversification of intelligences, which when contemplated in therapy, generate better results, in terms of the development of comprehension and verbal expression 
and nonverbal expression. However, they differ in the intelligences that are their preferred ones.

\section{REFERENCES}

1. Armstrong $T$. As inteligências múltiplas na sala de aula. $2^{\mathrm{a}}$ ed. Porto Alegre: Artmed Editora, 2001.

2. Gardner H. O nascimento e a Difusão de um "Meme". In: Gardner H, Chen J, Moran S (Eds). Inteligências Múltiplas ao redor do mundo. 1ed. Porto Alegre: Artmed, 2010. p.16-30.

3. Gardner H. Inteligencias múltiples: la teoria em la práctica. Tradução por María Teresa Melero Nogués. 1a ed. 4a reim. Buenos Aires: Paidós, 2011.

4. Shearer B. An Inter-rater Reliability Study of a Self-assessment for the Multiple Intelligences. Int $\mathrm{J}$ Psychol Stud. 2012;4(3):131-8.

5. Newcombe N. Desenvolvimento infantil. 8. ed. Porto Alegre: Artmed, 1999.

6. Brasil. Ministério da Saúde. Secretaria de políticas de Saúde. Acompanhamento do crescimento e desenvolvimento infantil. Brasília: Editora MS, 2002.

7. Bee H. A criança em desenvolvimento. 9. ed. Porto Alegre: Artmed, 2003.

8. WHO Multicentre Growth Reference Study Group. WHO Child Growth Standards: length/heightfor-age, weight-for-age, weight-for-length weightfor-height and body mass index-for-age: Methods and development. 1 ed. World Health Organization: Geneve, 2006.

9. Moran S. Por que Inteligências Múltiplas? In: Gardner H, Chen, JC, Moran S. Inteligências Múltiplas ao redor do mundo. 1ed. Porto Alegre: Artmed, 2010. p.380-9.

10. Moran S, Gardner H. Multiple intelligences in the workplace. In: Gardner $\mathrm{H}$ (Ed). Multiple intelligences: New horizons. 1 ed. New York: Basic Books. 2006. p. 213-32.

11. Fillmore CJ Baker C. A Frames approach to semantic analysis. In: Heine B, Narrog $H$. The Oxford Handbook of Linguistic Analysis. 1 ed. New York: Oxford University Press; 2009. p. 313-39.

12. Befi-Lopes DB, Cáceres AM, Esteves L. Linguistic profile of children with language impairment . Rev Soc Bras Fonoaudiol. 2012;17(3):274-8.

13. Bardin L. Análise de conteúdo. São Paulo: Edições 70, 2011.

14. Befi-Lopes DM, Nuñes CO, Cáceres AM. Correlation between expressive vocabulary and Mean Length
Utterancein children with language disorder. Rev. CEFAC. 2013;15(1):51-7.

15. Hedvall $\AA$, Westerlund J, Fernell E, Norrelgen $F$, Kjellmer L, Olsson MB et al. Preschoolers with autism spectrum disorder followed for 2 years: those who gained and those who lost the most in terms of adaptive functioning outcome. J Autism Dev Disord. 2015;45(11):3624-33. doi: http://dx.doi. org/10.1007/s10803-015-2509-3.

16. Pentimonti JM, Justice LM, Kaderavek JN. School-readiness profiles of children with language impairment: linkages to home and classroom experiences. Int $\mathrm{J}$ Lang Commun Disord. 2014;49(5):567-83. doi: http://dx.doi. org/10.1111/1460-6984.12094.

17. Ullrich D, Ullrich K, Marten M. A longitudinal assessment of early childhood education with integrated speech therapy for children with significant language impairment in Germany. Int $\mathrm{J}$ Lang Commun Disord. 2014;49(5):558-66.

18. Faja S, Dawson G, Sullivan K, Meltzoff AN, Estes $A$, Bernier R. Executive function predicts the development of play skills for verbal preschoolers with autism spectrum disorders. Autism Res. 2016;9(12):1274-84. doi: 10.1002/aur.1608.

19. Woo CC, Donnelly JH, Steinberg-Epstein R, Leon M. Environmental enrichment as a therapy for autism: A clinical trial replication and extension. Behav Neurosci. 2015;129(4):412-22. doi: 10.1037/ bne0000068.

20. Sun C, Zhang T, Bao BK, Xu C, Mei T. Discriminative exemplar coding for sign language recognition with Kinect. IEEE Trans Cybern. 2013;43(5):1418-28. doi: 10.1109/TCYB.2013.2265337.

21. Lerna A, Esposito D, Conson M, Massagli A. Long-term effects of PECS on social-communicative skills of children with autism spectrum disorders: a follow-up study. Int. J. Lang. Commun. 2014;49(4):478-85.

22. Netten AP, Rieffe C, Theunissen SC, Soede W, Dirks E, Briaire JJ, Frijns JH. Low empathy in deaf and hard of hearing (pre)adolescents compared to normal hearing controls. PLoS One. 2015;10(4):e0124102. doi: 10.1371/journal. pone.0124102.

23. Beck L. Relationship between language competence and emotional competence in middle childhood. Emotion. 2012;12(3):503-14.

24. Artigas-Pallarés J, Paula-Pérez I. Autismos que se ‘curan'. Rev Neurología. 2016;62(1):41-7. 
25. Greenslade KJ, Coggins TE. Assessing young children's intention-reading in authentic communicative contexts: preliminary evidence and clinical utility. Int $\mathrm{J}$ Lang Commun Disord. 2014;49(4):463-77. doi: 10.1111/1460-6984.12076.

26. Fillmore CJ. Frame semantics. In: Geeraerts D. (ed.). Cognitive linguistics - basic readings. 1 ed. Hawthorne: Mouton de Gruyter; 2006. p. 373-400.

27. Morato EM. A noção de frame no contexto neurolinguístico: o que ela é capaz de explicar? Cader Letr UFF. 2010;41:93-113.

28. Gardner H. Estruturas da Mente: A Teoria das Inteligências Múltiplas. Porto Alegre: Artes Médicas Sul, 1994.

29. Miranda NS, Bernardo FC. Frames, discurso e valores. Cad Est Lingui. 2013;55(1):81-97.

30. Lima FRO, Miranda NS. O Frame Semântico como uma ferramenta analítica de compreensão de experiências sociais educacionais. Gatilho. 2013;8(16):1-14.

31. Furnham A, Kosari A, Swami V. Estimates of self, parental and partner multiple intelligences in Iran: a replication and extension. Iran J Psychiatry. 2012;7(2):66-73.

32. Furnham A, Shagabutdinova K. Sex differences in estimating multiple intelligences in self and others: A replication in Russia. Int J Psychol. 2012;47(6):448-59. doi: 10.1080/00207594.2012.658054.

33. Neto $F$, da Conceição Pinto $M$, Mullet $E$, Furnham A. Estimates of lay views about reversal multiple intelligences for self and others: Sex and cross-cultural comparisons. Int $\mathrm{J}$ Psychol. 2015;1[s.l.]:1-10. doi: 10.1002/ijop.12241. [Epub ahead of print]

34. Neto F, Furnham A. Sex differences in parents' estimations of their own and their children's multiple intelligences: a portuguese replication. Span J Psychol. 2011;14(1):99-110.

35. Neto F, Furnham A, Pinto M da C. Estimating one's own and one's relatives' multiple intelligence: a cross-cultural study from East Timor and Portugal. Span J Psychol. 2009;12(2):518-27.

36. Szymanowicz A, Furnham A. Gender and gender role differences in self- and otherestimates of multiple intelligences. J Soc Psychol. 2013;153(4):399-423.
37. von Stumm S, Chamorro-Premuzic T, Furnham A. Decomposing self-estimates of intelligence: Structure and sex differences across 12 nations. $\mathrm{Br} J$ Psychol. 2009;100(Pt 2):429-42. doi: 10.1348/000712608X357876. 